\title{
Angiotensin II Suppresses Rev-erb $\alpha$ Expression in THP-1 Macrophages via the Ang II Type 1 Receptor/Liver X Receptor $\alpha$ Pathway
}

\author{
Shipeng Wang ${ }^{a, b} \quad$ Xia Guc Qi Zhang ${ }^{d} \quad$ Xiling Zhang ${ }^{a} \quad$ Yilan Li $^{a}$ \\ Yuan Yao ${ }^{e}$ Bo Yua,b Yao Zhang ${ }^{a, b}$ \\ a Department of Cardiology, The ${ }^{\text {nd }}$ Affiliated Hospital, Harbin Medical University, Harbin, ${ }^{\text {b Key }}$ \\ Laboratory of Myocardial Ischemia, Ministry of Education, Harbin Medical University, Harbin, \\ 'Department of Cardiology, Heilongjiang Provincial Hospital, Harbin, dDepartment of Cardiology, \\ Jiamusi City Center Hospital, Jiamusi City, e Department of Cardiology, The $1^{\text {st }}$ Affiliated Hospital, Hainan \\ Medical College, Haikou, China
}

\section{Key Words}

Angiotensin II $\bullet$ Rev-erb $\alpha \cdot$ Liver X receptor $•$ Macrophages $•$ Matrix metalloproteinase-9

\begin{abstract}
Background/Aims: Angiotensin II (Ang II) regulates the expression of some core clock genes; excess Ang II leads to atherosclerosis advancement. Macrophage Rev-erba mediates clockwork and inflammation, and plays a role in atherosclerotic lesion progression. However, the role of Ang II in regulating Rev-erba expression in macrophages remains unclarified. Methods: We induced THP-1 macrophages by phorbol 12-myristate 13-acetate and investigated the effect of Ang II on Rev-erba expression via real-time polymerase chain reaction, western blotting and small interfering RNA (siRNA) techniques. The cytotoxicity of the Rev-erba agonist SR9009 was analyzed using a (3-[4,5-dimethylthiazol-2-yl])-2,5- diphenyltetrazolium bromide assay. Results: Ang II suppressed Rev-erb $\alpha$ mRNA and protein expression in THP-1 macrophages in a dose and time dependent manner. This effect was mediated via Ang II type 1 receptor (AT1R), and not Ang II type 2 receptor or peroxisome proliferator-activated receptor $\gamma$ (PPAR $\gamma)$. Consistent with Rev-erb $\alpha$ expression regulated by Ang II, the liver X receptor $\alpha(L X R \alpha)$ protein expression was downregulated in a time-dependent manner after Ang II treatment. The activation or silence of LXR $\alpha$ significantly increased or decreased Rev-erbo expression regulated by Ang II, respectively. This suggests that $L X R \alpha$ is involved in the effect of Ang II on Rev-erbo expression. MMP-9 mRNA expressions were significantly suppressed by SR9009 in THP-1 and RAW264.7 macrophages; moreover, SR9009-treatment significantly reduced Ang II-induced MMP-9 protein expressions in two types of macrophages. Conclusion: Ang II downregulates Rev-erbo expression in THP-1 macrophages via the AT1R/LXR $\alpha$ pathway.

(C) 2018 The Author(s)

Published by S. Karger AG, Basel

Yao Zhang

Department of Cardiology, the $2^{\text {nd }}$ Affiliated Hospital of Harbin Medical University, Harbin 150001, (China)

Tel. (+86) 13633602663; Fax (+86) 86296225; E-Mail yaozhang_grace@163.com
\end{abstract}

KARGER 


\section{Cellular Physiology Cell Physiol Biochem 2018;46:303-313

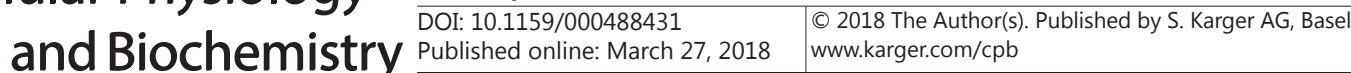

Wang et al.: Ang II Inhibits Rev-Erb $\alpha$ Expression via the AT1R/LXR $\alpha$ Pathway

\section{Introduction}

Acute myocardial infarction (AMI) mainly results from the rupture of vulnerable plaques in coronary vessels. Factors affecting plaque rupture include shear stress, macrophage infiltration, inflammation, and circadian rhythm variation during stress hormone release and infection $[1,2]$. Clinical studies have shown that the onset of AMI exhibits an obvious circadian variation [2-4]. It is believed that circadian variation in the incidence of plaque rupture mainly accounts for the characteristic circadian rhythm of AMI. Circadian stress hormone alterations comprise an important factor regulating diurnal variations of plaque rupture [1]. The mechanisms underlying this regulation are unclear; the circadian clock and clock-controlled genes in macrophages may be involved. In fact, previous studies have shown that the secretion of many proinflammatory cytokines associated with plaque rupture is gated by the circadian clock $[5,6]$.

Matrix metalloproteinases (MMPs) produced by activated cells (e.g., macrophages, smooth muscle cells, and endothelial cells) in inflamed atherosclerotic plaques are thought to weaken plaque caps and consequently promote plaque disruption through direct degradation of the extracellular matrix (ECM) [7]. Clinical and genetic studies have revealed that MMP-2 and MMP-9 are involved in the onset of acute coronary syndrome (ACS) [810]. In addition, excessive levels of angiotensin II (Ang II), the major stress hormone in the rennin-angiotensin system (RAS), have been confirmed to accelerate the progression of atherosclerotic plaques toward instability via MMPs induction [11,12]. These actions are mainly mediated through Ang II type 1 receptor (AT1R) $[11,13,14]$ and its downstream signaling molecules, including nuclear factor-kappa B (NF- $\kappa B$ ), liver X receptor $\alpha$ (LXR $\alpha$ ), Toll-like receptors (TLRs) and peroxisome proliferator-activated receptor $\gamma$ (PPAR $\gamma$ ) [1517]. Interestingly, Ang II also regulates the mRNA expression of some core clock and clock related genes, such as Period, Dbp, Bmal1, and Rev-erbo, in cultured vascular smooth muscle cells and hearts of rats $[18,19]$. However, the association between its effect on clock controlled genes and atherosclerotic plaque development is not well known.

Recently, macrophages were found to exhibit rhythmic expression of several clock genes, including Rev-erb $\alpha$, a member of the nuclear receptor (NR) superfamily [5]. Rev-erb $\alpha$, which is highly expressed in adipose tissue, muscle cells, and macrophages, regulates circadian rhythm, lipid, and glucose metabolism. It also plays important roles in inflammation and diseases, such as diabetes and atherosclerosis, through repressing transcription of target genes. Several studies have found that Rev-erb $\alpha$ is an important molecular component of the biological clock and a critical regulator of proper circadian timing [20,21]. Moreover, Rev-erb $\alpha$ may be a transcriptional link between circadian rhythmicity and cardiometabolic disease [22]. Recent studies have outlined the importance of Rev-erb $\alpha$ in atherosclerotic lesion progression. For example, in low-density lipoprotein (LDL) receptor-deficient mice, decreased Rev-erb $\alpha$ expression in hematopoietic cells led to increased atherosclerotic lesion size in the aortic root [23]. Consistent with this study, administration of synthetic Reverb $\alpha$ agonists was found to inhibit aortic atherosclerosis development in these mice [24]. Furthermore, in vitro research has shown that Rev-erb $\alpha$ suppresses MMP-9 gene expression in macrophages by inhibiting the transcription of enhancer-derived RNAs (eRNAs) [25], indicating a potential mechanistic connection between Rev-erb $\alpha$ activity and plaque disruption.

Ang II influences Rev-erbo expression in hearts of rats and has been shown to be involved in the regulation of MMPs expression in macrophages; however, the precise mechanisms by which Ang II controls Rev-erb $\alpha$ expression in macrophages and its relationship with MMPs regulation remain unknown.

In this study, we aimed to determine the effect of Ang II on Rev-erb $\alpha$ expression and investigate whether Rev-erb $\alpha$ could modulate Ang II-induced MMP-9 and MMP-2 expression in macrophages. We found that Ang II significantly downregulated Rev-erb $\alpha$ expression via the AT1R/LXR $\alpha$ signaling pathway. Moreover, our findings indicated that Ang II-induced upregulation of MMP-9 expression was suppressed by stimulation of Rev-erb $\alpha$. 


\section{Cellular Physiology Cell Physiol Biochem 2018;46:303-313 \begin{tabular}{l|l} 
and Biochemistry Published online: March 27, 2018 & $\begin{array}{l}\text { (c) } 2018 \text { The Author(s). Published by S. Karger AG, Basel } \\
\text { www.karger.com/cpb }\end{array}$
\end{tabular} \\ Wang et al.: Ang II Inhibits Rev-Erb $\alpha$ Expression via the AT1R/LXR $\alpha$ Pathway}

\section{Materials and Methods}

\section{Materials}

Ang II, phorbol 12-myristate 13-acetate (PMA), the PPAR- $\gamma$ agonist pioglitazone, the PPAR- $\gamma$ antagonist GW9662, the LXR $\alpha$ agonist T0901317, the NF- $\kappa$ B antagonist pyrrolidine dithiocarbamate (PDTC) and the Ang II type 2 receptor (AT2R) antagonist PD123319 were purchased from Sigma-Aldrich (St. Louis, MO, USA). SR9009 was purchased from MedChemExpress (Monmouth Junction, NJ, USA), and the AT1R antagonist valsartan was from Novartis (China). The cell culture medium RPMI 1640 and DMEM were from Corning (NY, USA), and fetal bovine serum (FBS) were from ScienCell (Carlsbad, CA, USA). TRIzol reagent for RNA isolation was from Invitrogen (Shanghai, china), and the one-step reverse transcription-polymerase chain reaction (RT-PCR) Kit and the SYBR Green 1 Real-Time RT-PCR kit were from Roche (Basel, BaselStadt, Switzerland). The rabbit monoclonal antibodies against human Rev-erb $\alpha$, human LXR $\alpha$ and human MMP-9 were purchased from Abcam Inc (Cambridge, MA, USA), and the mouse monoclonal antibody against $\beta$-actin was from ABclonal Inc (Cambridge, MA, USA). Anti-mouse/anti-rabbit conjugated antibodies were purchased from Zhongshan Golden Bridge Bio Co (Beijing, China). The Nuclear and Cytoplasmic Protein Extraction Kit, BCA Protein Assay Kit, and Enhanced Chemiluminescence (ECL) Kit were from Beyotime Institute of Biotechnology (Shanghai, China).

\section{Cell culture}

The human monocytic leukemia cell line THP-1 (Stem Cell Bank, Chinese Academy of Sciences) was incubated in RPMI 1640 medium with 10\% FBS in a humidified $95 \%$ air $/ 5 \% \mathrm{CO}_{2}$ atmosphere at $37{ }^{\circ} \mathrm{C}$. Then, cells were seeded onto a six-well plate at $1 \times 10^{6}$ cells $/ \mathrm{mL}$. In accordance with the literature [26], 160 $\mathrm{nM} / \mathrm{mL}$ PMA was added to the culture to induce macrophages differentiation. After $48 \mathrm{~h}$, the plates were washed thrice with $1 \mathrm{~mL}$ of phosphate-buffered saline (PBS). Adherent THP-1 macrophages were evaluated by CD68 immunofluorescence labeling to identify differentiation of THP-1 monocytes to macrophages. The RAW264.7 macrophage cell line (Shanghai Institute for Biological Science, the Chinese Academy of Sciences, Shanghai, China) was cultured in DMEM supplemented with 10\% FBS and the culture medium was replaced every 2-3 days. For subsequent experiments, the cells were cultured in serum-free medium for an additional $24 \mathrm{~h}$ and then maintained in complete culture medium for the next stimulus.

\section{Cell treatment}

To analyze Rev-erb $\alpha$ expression due to the effect of Ang II on THP-1 macrophages, cells were stimulated with Ang II $\left(10^{-9}, 10^{-8}, 10^{-7}\right.$, and $\left.10^{-6} \mathrm{M}\right)$ for different periods $(6,12$, and $24 \mathrm{~h})$. To identify the receptor subtypes involved in angiotensin II receptor blocker (ARB)-mediated regulation of Rev-erb $\alpha$ expression, macrophages were preincubated with the AT1 receptor blocker valsartan (10 $\mu \mathrm{M}$, non-PPAR $\gamma$-activating ARB), the AT2 receptor blocker PD $123319(10 \mu \mathrm{M})$, the PPAR $\gamma$ agonist pioglitazone $(10 \mu \mathrm{M})$, and the PPAR $\gamma$ antagonist GW9662 (10 $\mu \mathrm{M})$ for $2 \mathrm{~h}$ before Ang II treatment. Next, we investigated the effects of the NF- $\kappa \mathrm{B}$ inhibitor PDTC $(10 \mu \mathrm{M})$ and LXR $\alpha$ agonist T0901317 $(1 \mu \mathrm{M})$ on Rev-erb $\alpha$ expression induced by Ang II in THP-1 macrophages by preincubation for $30 \mathrm{~min}$ and $24 \mathrm{~h}$, respectively, before Ang II addition. In addition, cells were transfected with LXR $\alpha$ siRNA for $72 \mathrm{~h}$ before Ang II addition and pretreated with T0901317 $(1 \mu \mathrm{M})$ for $24 \mathrm{~h}$, separately. To confirm the role of LXR $\alpha$ in Rev-erb $\alpha$ expression downregulated by Ang II, cells were treated with Ang II $\left(10^{-6} \mathrm{M}\right)$ for different periods $(6,12$, and $24 \mathrm{~h})$. Then, THP-1 Macrophages and RAW264.7 macrophages were stimulated with Ang II to induce MMPs expression and cotreated with SR9009 $(10 \mu \mathrm{M})$ for $12 \mathrm{~h}$. To determine the role of Rev-erb $\alpha$ in MMP-9 protein expression induced by Ang II, THP-1 macrophages were preincubated with the AT1 receptor blocker valsartan $(10 \mu \mathrm{M})$ for $2 \mathrm{~h}$ and the LXR agonist T0901317 (1 $\mu \mathrm{M})$ for $24 \mathrm{~h}$, before Ang II-treatment, and subsequently cotreated with SR9009 $(10 \mu \mathrm{M})$ and Ang II for $12 \mathrm{~h}$, and transfected with LXR $\alpha$ siRNA for $72 \mathrm{~h}$ before Ang II addition, and pretreated with T0901317 (1 $\mu \mathrm{M})$ for $24 \mathrm{~h}$, separately. Unless stated otherwise, 10-6 M Ang II was used for $12 \mathrm{~h}$.

\section{(3-[4, 5-Dimethylthiazol-2-yl])-2, 5-diphenyltetrazolium bromide (MTT) assay}

The cytotoxicity of SR9009 was analyzed by MTT. THP-1 macrophages were seeded into 96-well plates at $1 \times 10^{5}$ cells per well with $100 \mu \mathrm{L}$ of RPMI-1640 medium. THP-1 macrophages were then stimulated with SR9009 $(1,5,10,50 \mu \mathrm{M})$ for $12 \mathrm{~h}$; the cells incubated in $0.1 \%$ dimethyl sulfoxide (DMSO) were defined as the control group. MTT ( $5 \mathrm{mg} / \mathrm{mL}$ ) reagent was added into each well. After incubation for $4 \mathrm{~h}$, the medium 


\section{Cellular Physiology Cell Physiol Biochem 2018;46:303-313

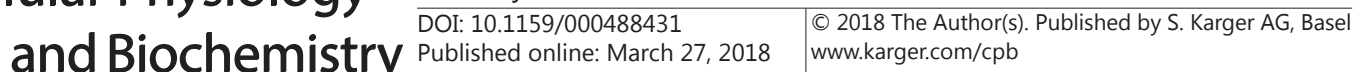

Wang et al.: Ang II Inhibits Rev-Erb $\alpha$ Expression via the AT1R/LXR $\alpha$ Pathway

was siphoned off and replaced with DMSO. The absorbance in each well was measured at 540nm using a microplate reader.

\section{Real-time PCR}

Total RNA was extracted from macrophages with TRIzol reagent according to the manufacturer's protocol. RNA quality was examined using an Experion Automated Electrophoresis System (BioRad, Hercules, CA, USA). First-strand cDNA was generated using reverse transcriptase (RT) and oligo dT primers (Transcriptor First Strand cDNA Synthesis Kit, Roche) and was then subjected to real-time RT-PCR amplification (PrimeScript RT reagent Kit Perfect Real Time, Roche). The following primers were used: hRev-erb $\alpha$ : 5'-GAC ATG ACG ACC CTG GAC TC-3' (forward), 5'-GCT GCC ATT GGA GTT GTC AC-3' (reverse); hMMP-9: 5' - AGT CCA CCC TTG TGC TCT TC-3' (forward), 5'-ACT CTC CAC GCA TCT CTG C-3' (reverse); and hMMP-2: 5'-ACC TGG ATG CCG TCG TGG AC-3' (forward), 5'-TGT GGC AGC ACC AGG GCA GC-3' (reverse); mMMP-9: 5'- CTG GAC AGC CAG ACA CTA AAG-3' (forward), 5'-CTC GCG GCA AGT CTT CAG AG-3' (reverse). Human and mouse $\beta$-actin (housekeeping gene) were amplified as an internal control for normalization. hRev-erb $\alpha$, hMMP-9, hMMP-2, mMMP-9, and $\beta$-actin expression was assessed via SYBR Green 1 fluorescence real-time RT-PCR. The CFX96 Real-Time PCR detection system (Bio-Rad) was used to directly monitor the PCR.

\section{RNA interference experiment}

Three small interfering RNA (siRNA) fragments against human LXR $\alpha$ and the nonsilencing siRNAs were synthesized by Ribobio (Guangzhou, China). THP-1 macrophages $\left(1 \times 10^{6}\right.$ cells/well) were transfected with each siRNA using ribo- FECTTMCP Reagent (Ribobio). After $72 \mathrm{~h}$, transfection efficiency was measured by western blotting. The second siRNA fragment (5'- TCA TCA AGG GAG CGC ACT A -3', LXR $\alpha$-siRNA) targeting LXR $\alpha$ suppressed LXR $\alpha$ expression by $70 \%$. Next, cells were treated with $10^{-6} \mathrm{M}$ Ang II for $12 \mathrm{~h}$, then harvested.

\section{Protein isolation and western blot analysis}

Treated THP-1 macrophages were lysed in radioimmunoprecipitation assay (RIPA) buffer and phenylmethanesulfonyl fluoride (PMSF) in ice for $30 \mathrm{~min}$. The protein deposit was obtained after centrifugation at 12, $000 \mathrm{~g}$ for $30 \mathrm{~min}$. Nucleic protein was extracted using the Nuclear and Cytoplasmic Protein Extraction Kit. The protein concentration was determined with the BCA protein assay kit, using bovine serum albumin (BSA) as a standard. Protein samples ( $40 \mu \mathrm{g}$ ) were used for sodium dodecyl sulfatepolyacrylamide gel electrophoresis (SDS-PAGE) on 10\% polyacrylamide gels and were transferred to a polyvinylidene difluoride (PVDF) membrane for $0.5 \mathrm{~h}$ at $15 \mathrm{~V}$. Membranes were blocked in $5 \%$ non-fat milk solution in Tris-buffered saline (TBS) buffer with $0.5 \%$ Tween 20 for $1 \mathrm{~h}$ at $22^{\circ} \mathrm{C}$. Then, the membranes were incubated overnight at $4^{\circ} \mathrm{C}$ with the specific primary antibodies anti-Rev-erb $\alpha(1: 2,000)$, anti-LXR $\alpha$ $(1: 3,000)$, and anti-MMP-9 $(1: 4,000)$. They were then washed three times in Tris-buffered saline with $0.1 \%$ Tween 20 (10 $\mathrm{min}$ for each wash) before incubation with the fluorescent-labeled secondary anti-rabbit antibody $(1: 8,000)$ for $1 \mathrm{~h}$ at $22^{\circ} \mathrm{C}$. $\beta$-actin antibody was used as a loading control. Immunoreactive bands were detected using the ECL Kit according to the manufacturer's instructions.

\section{Statistical analysis}

The SPSS13.0 software was used to analyze data from all experiments. Groups of data were compared with analysis of variance (ANOVA), followed by Student- Newman-Keuls multiple comparison tests. Data have been provided as mean \pm standard deviation (SD) values. $P<0.05$ was considered significant.

\section{Results}

\section{Assessment of macrophages differentiated from THP-1 cells}

THP-1 macrophages were identified by immunofluorescence. After PMA treatment for $48 \mathrm{~h}$, THP-1 macrophages have high expression of CD68 on their surface (data not shown), which demonstrated that THP-1 macrophages were successfully established. 


\section{Cellular Physiology Cell Physiol Biochem 2018;46:303-313 \begin{tabular}{l|l} 
and Biochemistry Published online: March 27, 2018 & $\begin{array}{l}\text { (c) 2018 The Author(s). Published by S. Karger AG, Basel } \\
\text { www.karger.com/cpb }\end{array}$
\end{tabular} \\ Wang et al.: Ang II Inhibits Rev-Erb $\alpha$ Expression via the AT1R/LXR $\alpha$ Pathway}

Rev-erba expression in THP-1 macrophages was suppressed by Ang-II stimulation

Real time RT-PCR and western blotting showed that Rev-erb $\alpha$ expression was significantly suppressed $(P<0.05)$ at the mRNA and protein levels (Fig. 1A), respectively, in THP-1 macrophages after incubation with different concentrations of Ang II. This suppression was maximum at the highest concentration of Ang II. Rev-erb $\alpha$ mRNA and protein expression levels at $6 \mathrm{~h}$ were significantly lower than those in the control group and reached a bottom at $12 \mathrm{~h}$ (Fig. 1B).

Involvement of Ang II receptor subtypes in Ang II-induced downregulation of Rev-erb $\alpha$

The antagonists valsartan and PD123319 were used to determine the roles of AT1R and AT2R in Ang II-induced downregulation of Rev-erb $\alpha$ expression. Preincubation with the AT1 receptor antagonist valsartan could significantly attenuate the effect of Ang II on Reverb $\alpha$ expression in macrophages $(P<0.01)$. However, blockade of AT2R did not influence the impact of Ang II on Rev-erbo expression (Fig. 2).

Previous studies have demonstrated that PPAR $\gamma$ agonism results from AT1 receptor blockade in the vasculature and that Rev-erb $\alpha$ can be upregulated by PPAR $\gamma$ in adipocytes $[15,27]$. Therefore, to determine whether the effect of Ang II on macrophage Rev-erb $\alpha$ expression is mediated by AT1R blockade or PPAR $\gamma$ activation, THP-1 macrophages were treated with the full PPAR $\gamma$ agonist pioglitazone and the PPAR $\gamma$ antagonist GW9662. Ang II-

Fig. 1. Rev-erb $\alpha$ mRNA and protein expression is downregulated by angiotensin (Ang) II in THP-1 macrophages. (A) Rev-erb $\alpha$ mRNA and protein expression was downregulated by Ang II in a concentration-dependent manner. THP-1 macrophages were treated in $12 \mathrm{~h}$ with different concentrations of Ang II $\left(10^{-9}, 10^{-8}, 10^{-7}\right.$, and $\left.10^{-6} \mathrm{M}\right)$. (B) Rev-erb $\alpha$ mRNA and protein expression was downregulated in 6, 12, and $24 \mathrm{~h}$ after Ang II $\left(10^{-6}\right.$ M) stimulation. The findings at different time points $(6,12$, and $24 \mathrm{~h})$ were examined. Rev-erbo expression was analyzed by western blotting (a) and real-time reverse transcription-polymerase chain reaction (b). Data from three independent experiments are shown relative to the controls and have been presented as mean \pm SD values. ${ }^{*} \mathrm{P}<0.05$ vs. control, ${ }^{* *} \mathrm{P}<0.01$ vs. control.

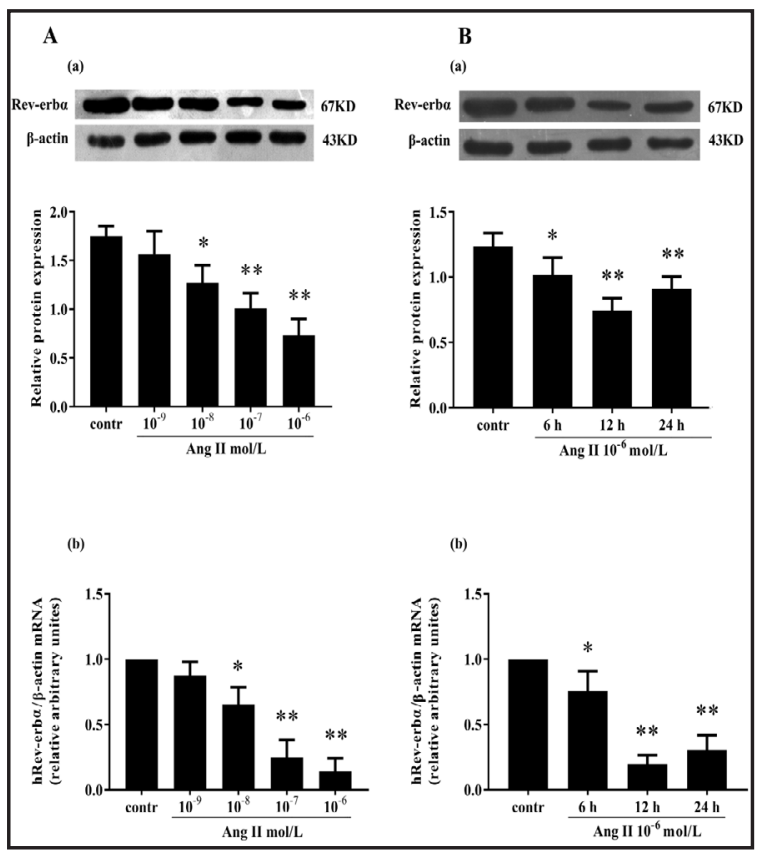

Fig. 2. Ang II receptor subtypes are involved in Ang II-induced downregulation of Rev-erb $\alpha$. THP-1 macrophages were preincubated with the AT1 receptor blocker valsartan $(10 \mu \mathrm{M}$, non-PPAR $\gamma$-activating ARB), AT2 receptor blocker PD123319 $(10 \mu \mathrm{M})$, the PPAR $\gamma$ agonist pioglitazone $(10 \mu \mathrm{M})$, and the PPAR $\gamma$ antagonist GW9662 $(10 \mu \mathrm{M})$ for $2 \mathrm{~h}$ before Ang II $\left(10^{-6} \mathrm{M}\right)$-treatment. RPMI 1640 medium served as the negative control. Representative results from western blotting for Reverb $\alpha$ are shown. Data from three independent experiments are shown relative to the controls and have been presented as mean \pm SD values. ${ }^{*} \mathrm{P}<0.01$ vs. control, $\# \mathrm{P}<0.01$ vs. Ang II.

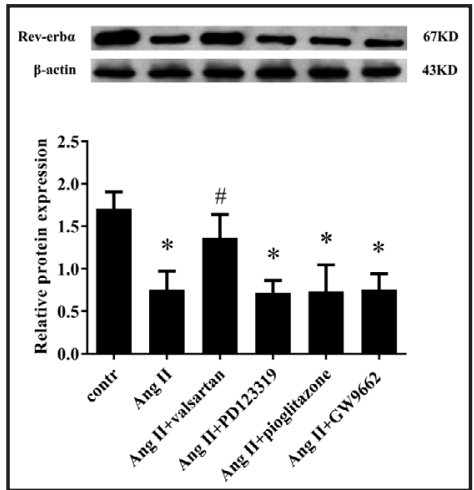




\section{Cellular Physiology \begin{tabular}{ll|l} 
and Biochemistry & $\begin{array}{l}\text { DOI: 10.1159/000488431 } \\
\text { Published online: March 27, } 2018\end{array}$ & $\begin{array}{l}\text { (c) } 2018 \text { The Author(s). Published by S. Karger AG, Basel } \\
\text { www.karger.com/cpb }\end{array}$
\end{tabular}

Fig. 3. Downregulation of Rev-erb $\alpha$ expression by Ang II is dependent upon liver X receptor $\alpha(\mathrm{LXR} \alpha)$ suppression. (A) LXR $\alpha$ siRNA significantly downreguated protein expression of LXR $\alpha$ in THP-1 macrophages. THP-1macrophages were transfected with LXR $\alpha$ siRNA for 72 h. (B) LXR $\alpha$ was involved in Rev-erb $\alpha$ protein expression following Ang II treatment. THP-1 macrophages were treated by either the synthetic LXR ligand T090137 $(1 \mu \mathrm{M})$ for $24 \mathrm{~h}$ or the antioxidant NF- $\kappa$ B inhibitor PDTC $(10 \mu \mathrm{M})$ for $30 \mathrm{~min}$, or transfected with LXR $\alpha$ siRNA in $72 \mathrm{~h}$ before Ang II stimulation in $12 \mathrm{~h}$, respectively. (C) LXR $\alpha$ protein expression in THP-1 macrophages after incubation with different time

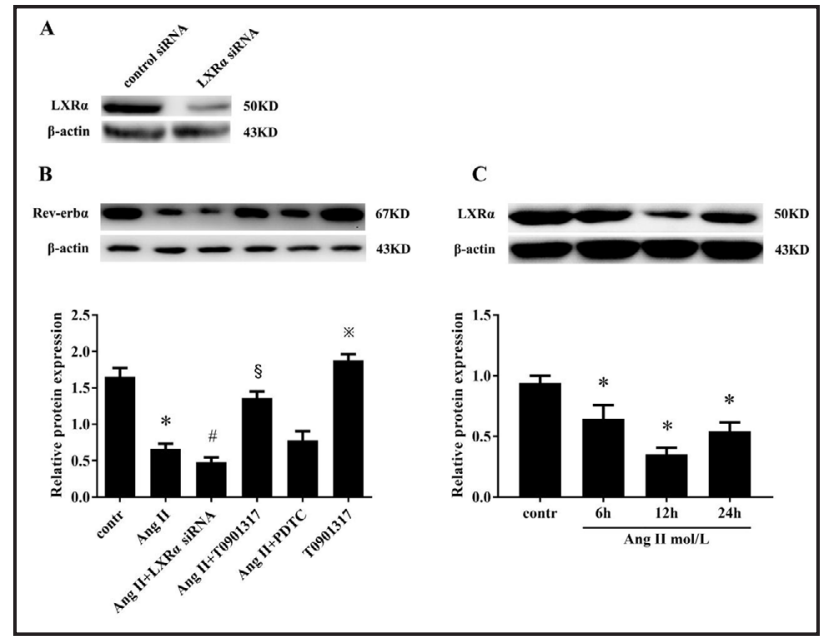
of Ang II $\left(10^{-6} \mathrm{M}\right)$. THP-1 macrophages were treated with Ang II $\left(10^{-6} \mathrm{M}\right)$. The findings at different time points $(6,12$, and $24 \mathrm{~h})$ were examined. Representative results from western blotting for Rev-erb $\alpha$ are shown. Data from three separately performed experiments are shown relative to the controls and have been presented as mean $\pm \mathrm{SD}$ values. ${ }^{*} \mathrm{P}<0.01$ vs. control, $※ \mathrm{P}<0.01$ vs. control, $\# \mathrm{P}<0.05$ vs. Ang II,§P<0.01vs. Ang II.

induced downregulation of Rev-erb $\alpha$ was unaffected by either the PPAR $\gamma$ agonist or PPAR $\gamma$ antagonist in THP-1 macrophages (Fig. 2).

Downregulation of Rev-erb $\alpha$ expression after Ang II treatment was dependent upon LXR $\alpha$ suppression

NF- $\mathrm{KB}$ and $\mathrm{LXR} \alpha$, which are downstream of AT1R in the inflammation response in macrophages, are activated and suppressed, respectively, by Ang II [28]. Therefore, we need investigate whether NF- $\mathrm{KB}$ activation and/or LXR $\alpha$ suppression are involved in the downregulation of Rev-erb $\alpha$ expression by Ang II. Our results indicated that Rev-erb $\alpha$ expression in T0901317 treated THP-1 macrophages was significantly higher than that in the control group $(P<0.01)$. Preincubation with T0901317 could significantly upregulate the expression of Rev-erb $\alpha$ suppressed by Ang II $(P<0.01$ vs. Ang II). However, modulation of Rev-erb $\alpha$ by Ang II was not affected by the antioxidant NF- $\kappa B$ inhibitor PDTC (Fig. 3B).

Then, the effect of LXR $\alpha$ silencing on Rev-erb $\alpha$ protein expression was examin- ed. SiRNAs targeting LXR $\alpha$ and the nonsilencing (control) siRNA were established, LXR $\alpha$ protein expression in LXR $\alpha$ siRNA group was significantly lower compared with that in control siRNA group, (Fig. 3A). As expected, LXR $\alpha$ silencing increased the inhibitory effect of Ang II on Reverb $\alpha$ expression $(P<0.05$ vs. Ang II). To confirm the role of LXR $\alpha$ in Rev-erb $\alpha$ expression downregulated by Ang II, we assessed LXR $\alpha$ protein expression in THP-1 macrophages after incubation with different time of Ang II $\left(10^{-6} \mathrm{M}\right)$. Consistent with Rev-erb $\alpha$ expression downregulated by Ang II, LXR $\alpha$ protein expression treated by Ang II was downregulated at $6 \mathrm{~h}$ and reached a trough at $12 \mathrm{~h}$, respectively (Fig. 3C). These results demonstrated that regulation of Rev-erb $\alpha$ expression by Ang II was dependent upon LXR $\alpha$ expression in THP-1 macrophages.

\section{Effect of the Rev-erb $\alpha$ agonist on MMPs mRNA expression in macrophages}

To determine whether SR9009 was toxic to THP-1 macrophages, cell viability was monitored by the MTT assay. THP-1 macrophages were stimulated with SR $9009(1,5,10$, and $50 \mu \mathrm{M}$ ) for $12 \mathrm{~h}$. The viability of THP-1 macrophages was not significantly affected by SR9009 at $1-10 \mu \mathrm{M}$, indicating the absence of significant cytotoxicity at these concentrations in THP-1 macrophages (Fig. 4A). 


\section{Cellular Physiology

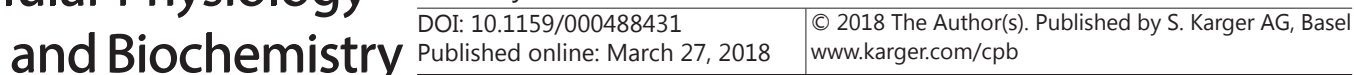

Fig. 4. Effect of the Rev-erb $\alpha$ agonist on matrix metalloproteinases (MMPs) mRNA expression in macrophages. (A) Effect of different concentrations of SR9009 on the viability of THP-1 macrophages. THP-1 macrophages were stimulated in $12 \mathrm{~h}$ with different concentrations of SR9009 $(1,5,10$, and $50 \mu \mathrm{M})$. Representative results from the MTT assay for THP-1 macrophage viability are shown. Data from three separately performed experiments are shown relative to the controls. (B) Effect of the Rev-erb $\alpha$ agonist on hMMP2 mRNA expression in THP-1 macrophages. (C) Effect of the Rev-erb $\alpha$ agonist on hMMP9 mRNA expression in THP-1 macrophages. (D) Effect of the Rev-erb $\alpha$ agonist on mMMP-

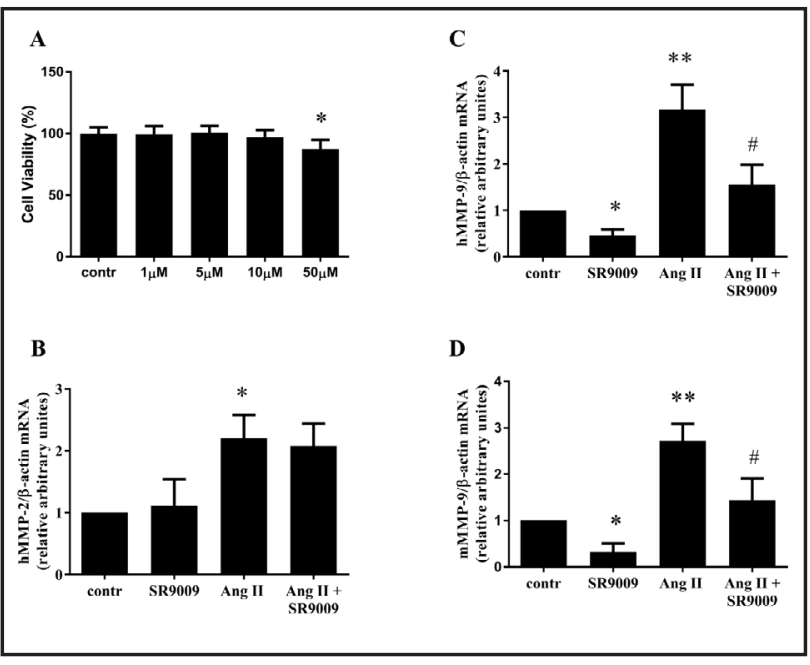
9 mRNA expression in RAW264.7 macro-

phages. macrophages were treated with the Rev-erb $\alpha$ agonist SR9009 $(10 \mu \mathrm{M})$, used either alone or along with Ang II (10 $\left.10^{-6} \mathrm{M}\right)$. MMP-2 and MMP-9 mRNA expression was analyzed by real-time RT-PCR from three and four independent experiments, respectively. Data are shown relative to the controls and have been presented as mean \pm SD values. ${ }^{*} \mathrm{P}<0.05$ vs. control, ${ }^{* *} \mathrm{P}<0.01$ vs. control, $\# \mathrm{P}<0.05$ vs. Ang II. hMMP - human MMP, MMMP - mouse MMP.

Fig. 5. Rev-erb $\alpha$ expression in relation to MMP-9 protein expression induced by Ang II in THP-1 macrophages. MMP9 protein expression was analyzed by western blotting. Seven groups (control, Ang II, Ang II + valsartan, Ang II + T0901317, Ang II + LXR $\alpha$ siRNA, Ang II + SR9009, and T0901317) were examined after Ang II treatment for $12 \mathrm{~h}$. Data from three independent experiments are expressed relative to the controls and have been presented as mean \pm SD values. $* \mathrm{P}<0.05$ vs. control, $※ \mathrm{P}<0.01$ vs. control, $\# \mathrm{P}<0.05$ vs. Ang II, $\S \mathrm{P}<0.01 v s$. Ang II.

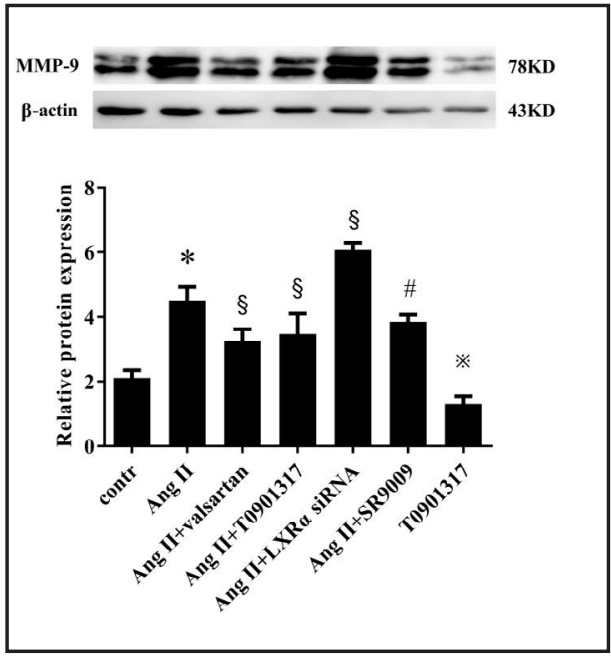

The effect of the Rev-erb $\alpha$ agonist on MMPs expression was examined by real-time RTPCR. THP-1 macrophages were treated with the Rev-erb $\alpha$ agonist SR9009, used either alone or along with Ang II. Human MMP-9 (hMMP-9) mRNA expression in SR9009-treated THP-1 macrophages significantly decreased after Ang II stimulation $(P<0.05$; Fig. 4C). Expression of hMMP-9 mRNA also decreased when cells were treated with SR9009 alone, without Ang II stimulation $(P<0.05)$. The effect of SR9009 was further confirmed on mouse MMP-9 (mMMP-9) mRNA expression in RAW264.7 macrophages (Fig. 4D). However, MMP-2 mRNA expression in THP-1 macrophages was unaffected by SR9009 treatment (Fig. 4B).

\section{Rev-erba expression in relation to MMP-9 protein expression induced by Ang II}

THP-1 macrophages in conditioned media were subjected to different treatments and accordingly divided into the control, Ang II, Ang II + valsartan, Ang II + T0901317, Ang II + LXR $\alpha$ siRNA, Ang II + SR9009 and T0901317 groups before western blotting (Fig. 5). MMP9 protein expression in the Ang II-treated group was significantly higher than that in the 


\section{Cellular Physiology Cell Physiol Biochem 2018;46:303-313 \\ \begin{tabular}{l|l} 
DOI: 10.1159/000488431 & $\begin{array}{l}\text { O 2018 The Author(s). Published by S. Karger AG, Basel } \\
\text { www.karger.com/cpb }\end{array}$
\end{tabular} \\ Wang et al.: Ang II Inhibits Rev-Erb $\alpha$ Expression via the AT1R/LXR $\alpha$ Pathway}

control group $(P<0.05)$. This regulation could be depressed by treatment with valsartan, T0901317, and SR9009, respectively. However, LXR $\alpha$ siRNA treatment significantly increased MMP-9 protein expression in THP-1 macrophages treated with Ang II $(P<0.01$ vs. Ang II). As expected, MMP-9 protein expression in the T0901317-treated group was significantly lower than that in the control group $(P<0.01)$. Thus, MMP-9 protein expression was related to Rev-erbo expression.

\section{Discussion}

To our knowledge, the current study is the first to show that Ang II stimulation can decrease Rev-erb $\alpha$ expression in THP-1 macrophages and that this effect is mainly mediated via the AT1R /LXR $\alpha$ signaling pathway. Moreover, the agonist of Rev-erb $\alpha$ markedly reduced MMP-9 expression under Ang II stimulation in macrophages.

The circadian rhythm is a biological process that is controlled by clock signals such as light, food, and hormones. As a clock-controlled gene, Rev-erbo is also believed to be entrained and modulated by humoral factors including hormones in serum [29]. Ang II, a stress hormone, is an attractive candidate for clock cues because it is released into the serum in daily cycles and can induce clock gene expression in smooth muscle cells and cardiomyocytes $[18,19]$. Herichová et al. found that 28-day infusion of Ang II modified Reverb $\alpha$ mRNA expression in hearts of Wistar rats [19]. We also found that Rev-erb $\alpha$ expression was regulated by Ang II in THP-1 macrophages. These findings expand our understanding of the role of RAS in clock and clock-controlled genes expression.

The effect of Ang II on clock gene expression has been confirmed to be predominantly mediated via AT1R [18]. Therefore, we investigated the functional role of AT1R in the regulation of Rev-erba gene expression. Our results showed that Ang II regulated Reverb $\alpha$ expression through AT1R in THP-1 macrophages. However, previous research has demonstrated that Ang II downregulates PPAR- $\gamma$ expression and that AT1R blockade leads to PPAR- $\gamma$ stimulation in the vasculature [15]. Therefore, the effect of PPAR- $\gamma$ should also be considered while studying the effect of Ang II on Rev-erb $\alpha$ expression. Here, we found that the effect of PPAR- $\gamma$ in macrophages was not involved in the regulation of Rev-erb $\alpha$ expression by Ang II. However, PPAR- $\gamma$ has been reported to induce Rev-erb $\alpha$ expression during murine adipocyte differentiation [27]. These contradictory results indicate that the regulation of Rev-erb $\alpha$ expression is pathway-specific in different cell lines.

The regulation of NRs on Rev-erb $\alpha$ in different types of cells and tissues has been studied. Previous research has indicated that Rev-erbo expression is downregulated by glucocorticoids via their receptor mechanism in both rats and human primary hepatocytes [30]. Basic research also has shown that PPAR $\alpha$ and PPAR $\gamma$ induce Rev-erb $\alpha$ expression in liver and adipose tissues, respectively [27, 31]. Moreover, Fontaine et al. found that LXRs regulate Rev-erb $\alpha$ in human macrophages [32]. Consistent with these previous studies, our current results indicated that LXR $\alpha$ regulates Rev-erb $\alpha$ protein expression following Ang II treatment in human macrophages. The regulatory mechanism of LXR $\alpha$ for Rev-erb $\alpha$ has been confirmed by recent research demonstrating that LXR $\alpha$ binds as a heterodimer with the retinoid X receptor $\alpha(\mathrm{RXR} \alpha)$ to the human Rev-erb $\alpha$ promoter and induces the transcriptional activity of Rev-erb $\alpha$ [32]. In addition, recent research has demonstrated that LXR $\alpha$, one of the NRs controlling cholesterol homeostasis and inflammation, is inhibited by Ang II in macrophages [28]. Collectively, these evidences indicate that the regulation of Ang II on Rev-erb $\alpha$ expression is LXR $\alpha$-dependent, at least in part, in THP-1 macrophages.

The circadian variation of atherosclerotic lesion rupture might be attributed, at least in part, to circadian oscillation of genes relevant to the ECM [33] and circadian fluctuation of MMPs [34]. Moreover, mutation of circadian genes has been shown to lead to vascular stiffness via MMPs dysregulation [35]. Thus, molecular circadian clock dysfunction is proposed to be involved in the progression of atherosclerotic plaque. In the current study, our results showed that Rev-erb $\alpha$ is involved in regulating MMP-9 expression in human and mouse 


\section{Cellular Physiology Cell Physiol Biochem 2018;46:303-313 \begin{tabular}{c|c|c|} 
DOI: 10.1159/000488431 & and Biochemistry \\
Published online:March 27, 2018 & $\begin{array}{l}\text { O 2018 The Author(s). Published by S. Karger AG, Basel } \\
\text { www.karger.com/cpb }\end{array}$
\end{tabular} \\ Wang et al.: Ang II Inhibits Rev-Erb $\alpha$ Expression via the AT1R/LXR $\alpha$ Pathway}

macrophages. Thus, we speculate that Rev-erb $\alpha$ may serve to integrate ECM degradation functions of MMP-9 and circadian signals in macrophages. Moreover, the inhibitory effect of Rev-erb $\alpha$ on MMP-9 expression induced by Ang II suggests that the increase in Reverb $\alpha$ expression could relieve degradation of the ECM in atherosclerotic plaques, and thus mediates, at least in part, the Ang II effect on atherosclerotic progression. In a recent study, AT1R antagonism was found to repress intimal neovascularization in atherosclerotic plaques in apolipoprotein E-deficient mice, partly by reducing inflammatory effects mediated by TLRs and MMPs activation [14]. In addition, human TLR-4 promoter activity is inhibited by Rev-erb $\alpha$, which binds with the LXR $\alpha$ response element site in the TLR-4 promoter [31]. Together, these data provide some indication regarding how NR Rev-erb $\alpha$ influences the development of RAS-induced atherosclerotic plaques, suggesting that Rev-erb $\alpha$ might be a potential therapeutic target for vulnerable plaque.

Studies on rats and mice have indicated that Rev-erb $\alpha$ expression reaches a peak during the daytime and trough in the nighttime in peripheral tissues and organs, such as the liver, heart, immune system components and adipose tissues $[5,19,36]$. The morning peak incidence of cardiovascular events has a significant implication that circadian variation of Rev-erb $\alpha$ might correlate with the attack of ACS. Although a direct functional role of Reverb $\alpha$ in ACS has not yet been shown, our observation raises the possibility that Rev-erb $\alpha$ in plaques might influence pathogenesis of ACS by its effect on MMPs. Thus, further research on circadian variation of Rev-erb $\alpha$ expression in atherosclerotic plaques is required to improve understanding of the relation between Rev-erbo and ACS.

Rev-erb $\alpha$ and retinoic acid receptor-related orphan receptors- $\alpha(\mathrm{ROR} \alpha)$, which recognize and compete for the same response elements in the genome, regulate the expression of genes involved in immune function, muscle metabolism, and lipid and glucose homeostasis [37]. Recent research has revealed that this dual regulation is related to gene expression of proinflammatory cytokines in macrophages [38]. Therefore, further research is required to determine the competitive relationship of the two receptors in MMP-9 regulation in macrophages. However, Zhang et al. have recently suggested that the tissue-specific nonclock genes targeted by Rev-erb $\alpha$ are regulated independent of competition from ROR $\alpha$ [39]. In addition, further investingations are required to elucidate the involvement of other clockrelated genes controlled by Ang II on MMPs expression.

We have to point out that this study has examined the effect of Ang II on Rev-erb $\alpha$ expression only in THP-1 macrophages and further research need be performed in peritoneal macrophages or bone marrow-derived mouse macrophages.

In summary, we have shown that Ang II can downregulate Rev-erb $\alpha$ expression in THP-1 macrophages via AT1R and that the LXR $\alpha$ pathway plays an important part in this effect. In addition, Rev-erb $\alpha$ is involved in Ang II-regulated MMP-9 expression in macrophages, which may provide a new therapeutic target for the treatment of atherosclerotic plaques.

\section{Acknowledgements}

We thank Wei Wang for technical assistance. The present study was supported by grants from the national natural science foundation of China (no.81770255) and the natural science foundation of Heilongjiang province of China (no.H2013104).

\section{Disclosure Statement}

No conflict of interests exists. 


\section{Cellular Physiology Cell Physiol Biochem 2018;46:303-313

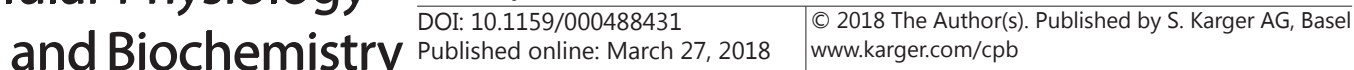 \\ Wang et al.: Ang II Inhibits Rev-Erb $\alpha$ Expression via the AT1R/LXR $\alpha$ Pathway}

\section{References}

1 Monroe VS, Kerensky Ra, Rivera E, Smith KM, Pepine CJ: Pharmacologic plaque passivation for the reduction of recurrent cardiac events in acute coronary syndromes. J Am Coll Cardiol 2003;41:20S-30S.

-2 Tanaka A, Kawarabayashi T, Fukuda D, Nishibori Y, Sakamoto T, Nishida Y, Shimada K, Yoshikawa J: Circadian variation of plaque rupture in acute myocardial infarction. Am J Cardiol 2004;93:1-5.

-3 Muller JE, Stone PH, Turi ZG, Rutherford JD, Czeisler CA, Parker C, Poole WK, Passamani E, Roberts R, Robertson T: Circadian variation in the frequency of onset of acute myocardial infarction. N Engl J Med 1985;313:1315-1322.

-4 Shaw E, Tofler GH: Circadian rhythm and cardiovascular disease. Curr Atheroscler Rep 2009;11:289-295.

-5 Keller M, Mazuch J, Abraham U, Eom GD, Herzog ED, Volk HD, Kramer A, Maier B: A circadian clock in macrophages controls inflammatory immune responses. Proc Natl Acad Sci U S A 2009;106:21407-21412.

-6 Gibbs JE, Blaikley J, Beesley S, Matthews L, Simpson KD, Boyce SH, Farrow SN, Else KJ, Singh D, Ray DW: The nuclear receptor REV-ERB $\alpha$ mediates circadian regulation of innate immunity through selective regulation of inflammatory cytokines. Proc Natl Acad Sci U S A 2012;109:582-587.

7 Newby AC: Metalloproteinase expression in monocytes and macrophages and its relationship to atherosclerotic plaque instability. Arterioscler Thromb Vasc Biol 2008;28:2108-2114.

8 Kai H, Ikeda H, Yasukawa H, Kai M, Seki Y, Kuwahara F, Ueno T, Sugi K, Imaizumi T: Peripheral blood levels of matrix metalloproteases- 2 and -9 are elevated in patients with acute coronary syndromes. J Am Coll Cardiol 1998;32:368-372

9 Ferroni P, Basili S, Martini F, Cardarello CM, Ceci F, Di Franco M, Bertazzoni G, Gazzaniga PP, Alessandri C: Serum metalloproteinase 9 levels in patients with coronary artery disease: a novel marker of inflammation. J Investig Med 2003;51:295-300.

-10 Eckart RE, Uyehara CF, Shry EA, Furgerson JL, Krasuski RA: Matrix metalloproteinases in patients with myocardial infarction and percutaneous revascularization. J Interv Cardiol 2004;17:27-31.

-11 Husain K, Hernandez W, Ansari RA, Ferder L: Inflammation, oxidative stress and renin angiotensin system in atherosclerosis. World J Biol Chem 2015;6:209-217.

12 Sato K, Nakano K, Katsuki S, Matoba T, Osada K, Sawamura T, Sunagawa K, Egashira K: Dietary cholesterol oxidation products accelerate plaque destabilization and rupture associated with monocyte infiltration/ activation via the MCP-1-CCR2 pathway in mouse brachiocephalic arteries: therapeutic effects of ezetimibe. J Atheroscler Thromb 2012;19:986-998.

13 Aono J, Suzuki J, Iwai M, Horiuchi M, Nagai T, Nishimura K, Inoue K, Ogimoto A, Okayama H, Higaki J: Deletion of the angiotensin II type 1a receptor prevents atherosclerotic plaque rupture in apolipoprotein E-/- mice. Arterioscler Thromb Vasc Biol 2012;32:1453-1459.

14 Cheng XW, Song HF, Sasaki T, Hu L, Inoue A, Bando YK, Shi G-P, Kuzuya M, Okumura K, Murohara T: Angiotensin type 1 receptor blocker reduces intimal neovascularization and plaque growth in apolipoprotein E-deficient mice. Hypertension 2011;57:981-989.

-15 Tham DM, Martin-McNulty B, Wang YX, Wilson DW, Vergona R, Sullivan ME, Dole W, Rutledge JC: Angiotensin II is associated with activation of NF-kappaB-mediated genes and downregulation of PPARs. Physiol Genomics 2002;11:21-30.

-16 Alrashed F, Kochumon S, Usmani S, Sindhu S, Ahmad R: Pam3CSK4 Induces MMP-9 Expression in Human Monocytic THP-1 Cells. Cell Physiol Biochem 2017;41:1993-2003.

17 Sindhu S, Alroub A, Koshy M, Thomas R, Ahmad R: Palmitate-Induced MMP-9 Expression in the Human Monocytic Cells is Mediated through the TLR4-MyD88 Dependent Mechanism. Cell Physiol Biochem 2016;39:889-900.

18 Nonaka H, Emoto N, Ikeda K, Fukuya H, Rohman MS, Raharjo SB, Yagita K, Okamura H, Yokoyama M: Angiotensin II induces circadian gene expression of clock genes in cultured vascular smooth muscle cells. Circulation 2001;104:1746-1748.

19 Herichova I, Soltesova D, Szantoova K, Mravec B, Neupauerova D, Vesela A, Zeman M: Effect of angiotensin II on rhythmic per2 expression in the suprachiasmatic nucleus and heart and daily rhythm of activity in Wistar rats. Regul Pept 2013;186:49-56.

20 Preitner N, Damiola F, Lopez-Molina L, Zakany J, Duboule D, Albrecht U, Schibler U: The orphan nuclear receptor REV-ERBalpha controls circadian transcription within the positive limb of the mammalian circadian oscillator. Cell 2002;110:251-260. 


\section{Cellular Physiology Cell Physiol Biochem 2018;46:303-313 \begin{tabular}{l|l} 
DOI: 10.1159/000488431 & $\begin{array}{l}\text { O 2018 The Author(s). Published by S. Karger AG, Basel } \\
\text { www.karger.com/cpb }\end{array}$
\end{tabular} \\ Wang et al.: Ang II Inhibits Rev-Erb $\alpha$ Expression via the AT1R/LXR $\alpha$ Pathway}

21 Crumbley C, Burris TP: Direct regulation of CLOCK expression by REV-ERB. Plos One 2011;6:e17290.

22 Fontaine C, Staels B: The orphan nuclear receptor Rev-erbalpha: a transcriptional link between circadian rhythmicity and cardiometabolic disease. Curr Opin Lipidol 2007;18:141-146.

23 Ma H, Zhong W, Jiang Y, Fontaine C, Li S, Fu J, Olkkonen VM, Staels B, Yan D: Increased atherosclerotic lesions in LDL receptor deficient mice with hematopoietic nuclear receptor Rev-erbalpha knock-down. J Am Heart Assoc 2013;2:e000235.

24 Sitaula S, Billon C, Kamenecka TM, Solt LA, Burris TP: Suppression of atherosclerosis by synthetic REV-ERB agonist. Biochem Biophys Res Commun 2015;460:566-571.

25 Lam MT, Cho H, Lesch HP, Gosselin D, Heinz S, Tanaka-Oishi Y, Benner C, Kaikkonen MU, Kim AS, Kosaka M, Lee CY, Watt A, Grossman TR, Rosenfeld MG, Evans RM, Glass CK: Rev-Erbs repress macrophage gene expression by inhibiting enhancer-directed transcription. Nature 2013;498:511-515.

26 Park EK, Jung HS, Yang HI, Yoo MC, Kim C, Kim KS: Optimized THP-1 differentiation is required for the detection of responses to weak stimuli. Inflamm Res 2007;56:45-50.

27 Fontaine C, Dubois G, Duguay Y, Helledie T, Vu-Dac N, Gervois P, Soncin F, Mandrup S, Fruchart JC, FruchartNajib J: The orphan nuclear receptor Rev-Erb alpha is a peroxisome proliferator-activated receptor (PPAR) gamma target gene and promotes PPAR gamma-induced adipocyte differentiation. J Biol Chem 2003;278:37672-37680.

28 Yang HY, Bian YF, Xiao CS, Liang B, Zhang N, Gao F, Yang ZM: Angiotensin-(1-7) stimulates cholesterol efflux from angiotensin II-treated cholesterol-loaded THP-1 macrophages through the suppression of p38 and c-Jun N-terminal kinase signaling. Mol Med Rep 2015;12:1387-1392.

-29 Balsalobre A: A Serum Shock Induces Circadian Gene Expression in Mammalian Tissue Culture Cells. Cell 1998;93:929-937.

-30 Torra IP, Tsibulsky V, Delaunay F, Saladin R, Laudet V, Fruchart JC, Kosykh V, Staels B: Circadian and glucocorticoid regulation of Rev-erbalpha expression in liver. Endocrinology 2000;141:3799-3806.

-31 Gervois P, Chopin-Delannoy S, Fadel A, Dubois G, Kosykh V, Fruchart JC, Najib J, Laudet V, Staels B: Fibrates increase human REV-ERBalpha expression in liver via a novel peroxisome proliferator-activated receptor response element. Mol Endocrinol 1999;13:400-409.

-32 Fontaine C, Rigamonti E, Pourcet B, Duez H, Duhem C, Fruchart JC, Chinetti-Gbaguidi G, Staels B: The nuclear receptor Rev-erbalpha is a liver X receptor (LXR) target gene driving a negative feedback loop on select LXR-induced pathways in human macrophages. Mol Endocrinol 2008;22:1797-1811.

-33 Rudic RD, McNamara P, Reilly D, Grosser T, Curtis AM, Price TS, Panda S, Hogenesch JB, FitzGerald GA: Bioinformatic analysis of circadian gene oscillation in mouse aorta. Circulation 2005;112:2716-2724.

-34 Dominguez-Rodriguez A, Abreu-Gonzalez P, Garcia-Gonzalez MJ, Reiter RJ: Relation of nocturnal melatonin levels to serum matrix metalloproteinase- 9 concentrations in patients with myocardial infarction. Thromb Res 2007;120:361-366.

-35 Anea CB, Ali MI, Osmond JM, Sullivan JC, Stepp DW, Merloiu AM, Rudic RD: Matrix metalloproteinase 2 and 9 dysfunction underlie vascular stiffness in circadian clock mutant mice. Arterioscler Thromb Vasc Biol 2010;30:2535-2543.

-36 Zvonic S, Ptitsyn AAConrad SA, Scott LK, Floyd ZE, Kilroy G, Wu X, Goh BC, Mynatt RL, Gimble JM: Characterization of peripheral circadian clocks in adipose tissues. Diabetes 2006;55:962-970.

-37 Butler AA, Burris TP: Segregation of Clock and Non-Clock Regulatory Functions of REV-ERB. Cell Metab 2015;22:197-198.

-38 Sato S, Sakurai T, Ogasawara J, Takahashi M, Izawa T, Imaizumi K, Taniguchi N, Ohno H, Kizaki T: A circadian clock gene, Rev-erbalpha, modulates the inflammatory function of macrophages through the negative regulation of Ccl2 expression. J Immunol 2014;192:407-417.

-39 Zhang Y, Fang B, Emmett MJ, Damle M, Sun Z, Feng D, Armour SM, Remsberg JR, Jager J, Soccio RE, Steger DJ, Lazar MA: GENE REGULATION. Discrete functions of nuclear receptor Rev-erbalpha couple metabolism to the clock. Science 2015;348:1488-1492. 